DOI https://doi.org/10.36059/978-966-397-158-2/135-152

\title{
POLITICAL RISKS AS A SOCIO-POLITICAL PHENOMENON IN THE ASPECT OF MODERNIZATION OF THE POLITICAL PROCESS
}

\section{Pekhnyk A. V.}

\section{INTRODUCTION}

Changes in the modern world, the growth of elements of unpredictability in public life, the uncertainty of the nature of political processes, the need to find the means to take into account the factors of uncertainty in political activities determine the feasibility of investigating the mechanism of the relationship of risk and technology to the actual implementation of the political process. The crisis in Ukraine reduces the level of governance, makes it impossible to solve economic and social problems in a timely manner, the authorities lose the confidence of citizens and threaten democracy. The authorities must not only be able to lead the society out of the crisis, but also to prevent new crises from occurring. In order to be aware of the likelihood of a crisis, risks, including political risks, must be considered. Globalization processes are accompanied by risk in all spheres of activity due to the uncertainty, controversy and ambiguity of the nature of these processes. Significant political risk factors, along with the stated restriction on the sovereignty of the nation-state, are risks in the activities of decision-making governments, as well as actualization of environmental hazards, rising energy prices, international trends in capital movements, global drug trade, rising terrorism, etc. In order to influence the risk factors, it is necessary to study them carefully.

Risk research is an attempt to adapt to the globalized world. The need to study policy and political risks is linked to the need to analyze, predict and model the development of political processes in order to preserve statehood and pursue their own interests within a democracy.

\section{Risk as an object of study in various sciences}

Risk is the object of study in various sciences. Most of the economic works today study the risk associated with investment, insurance, financial activities, risk in business, in the banking sector, and at risk is the risk of incurring losses. Less relevant research in philosophy, law practice, 
sociology, psychology, which consider risk as a form of manifestation of human behavior. It should be noted that risk in politics can include not only the political component, but also a wide range of economic, organizational, social, psychological, manipulative and other actions, it is wider in the content of the category «political risk».

The need to study policy risks is linked to the need to analyze, predict and model the development of political processes in order to preserve statehood and pursue their own interests. And if philosophy, synergetics pose a problem, then the study of risk aims to solve it, to help adapt to the situation of uncertainty.

M. Levchenko defines that «the structure of political risk research includes four stages: a comprehensive analysis of the field of research; systematic assessment of political risk factors; political risk forecasting; political risk management.» ${ }^{1}$ And we have to agree with that.

Until the XVII century, there was no general concept for risk. At the time, it was only about fate or rock or fortune. A new era that changed the understanding of destiny, ideals and goals also brought a new awareness of risk as a key factor in human activity and as one of the conditions for success. The origin of the word «risk» comes from the Portuguese language and translates as «rock», which, in turn, penetrated into Portuguese from the Greek language, which meant «stream». The term «risk» from the Latin «risicare» means «to decide.» In theory and practice, the concept of risk is multilateral and ambiguous.

In most cases, the term «risk» (political, social) is defined as the likelihood of unwanted events. The category «political risk» has appeared in the lexicon of foreign multinationals and banks, which have suffered significant financial losses in foreign markets, especially in countries with so-called transition economies. Risk has been studied to assess the social and political situation in countries of possible investment. Political risk was understood as the risks to which companies in other countries were exposed, assessed as a deterioration of economic activity of entities in foreign markets as a result of the influence of political factors: conflicts, instability, the rise of nationalism, fundamentalism. In all cases, we are talking about the negative impact of political causes on the economy. This understanding of political risk has become entrenched in modern political science. However, it should be noted that this position is very narrow and reflects only the

Левченко М. О. Політичний ризик як один із факторів впливу зовнішньоекономічної діяльності машинобудівного підприємства. Економічний вісник Донбасу. 2011. № 2(24). C. 53-57. URL: http://www.evd-journal.org/download/2011/ 2011-2/Ek_visnyk_2_2011-53-57.pdf. 
utilitarian interests and goals of the investor country. Depending on the purpose, risk assessment and approaches to risk factors may also change.

The modern state is increasingly faced with the need to analyze risks in various aspects not only of foreign but also of domestic policy. Emerging markets and democratization processes increase political instability. It is not only about revolutions, coups, changes in government and exchange rate, but also risks that do not pose a threat to the investor country, on the contrary, are a real threat to national security and political stability, which is caused by internal political processes. Powerful political decisions at the national level do not necessarily affect the activities of foreign companies, dramatically or substantially affecting domestic political processes in economic, political, social and other spheres.

Risks in political activity in the structure of riskology are one of the main research objects, because many kinds of economic, psychological, social and other risks are largely related to the political stability and legitimacy of the authorities. When studying the implementation of a political process, risk theory deals with the problems of its manifestation in political activity, the risks associated with the functioning of the political system, the analysis of the degree of admissibility, social acceptability and justification, the choice of optimal, appropriate technologies for policy implementation. Development of methods that allow to analyze effectively, identify, evaluate risks in political activity, to take it into account in the technologies of political process implementation - is a necessity dictated by the needs of today. But despite this, the problem of risk in the political process is not sufficiently developed for Ukrainian science.

In modern foreign and domestic literature there is no single, commonly accepted definition of the category «risk». Depending on the area of scientific interests of the authors, various phenomena, states and processes are called «risk». But everyone recognizes that risk is a meaningful, multifaceted and unpredictable phenomenon in various processes, including political.

Political risk issues have been the subject of debate in science since the late 1960s. However, attempts to take into account the political risk posed by the actions of individual statesmen or governments were made in the 19th century. So, the Rothschild banker organized a system of information about political events that he received news about them a few days before the government.

In scientific circulation, the term «risk» was introduced by the American researcher F.Knight. In his view, uncertainty and risk should be distinguished. «Risk or likelihood complements to some extent the 
theoretical analysis of empirical data research $»^{2}$. A large number of authors use the term «risk» as a synonym for uncertainty. In this case, they are talking about deciding in uncertainty instead of deciding in risk. Naturally, there are appropriate logical reasons for this, because risk is one of the means of overcoming uncertainty and arises only in a situation of uncertainty about the possibility of achieving the intended result.

In the field of politics, in particular, this means that in a situation of uncertainty, a political entity does not have complete information about alternatives to solving a problem, their usefulness and he is not aware of the likelihood of a political situation, events that are influenced by a large number of external factors. It is in this situation that his actions become risky. That is, the concept of «risk» is used to refer to an objective uncertainty that is subject to regulation, whereas the concept of «uncertainty» is necessary to denote an irrationality given.

There are different approaches in the political, legal, and philosophical literature to understanding the relation between objective and subjective in the phenomenon of «risk». First, there is a widespread view that risk is a phenomenon that has only objective meaning because it is determined by human-independent conditions. Risk is a form of describing real uncertainty, its expression in quantitative and qualitative characteristics, and corresponds to some objective regularities of social life. This is the objectivity of the risk that exists regardless of whether or not political subjects are aware of it, whether they consider it or not in their activities.

In general, the concept of "political risk» appeared in the lexicon of American corporations in 1959 after F. Castro came to power in Cuba. Political risk can be found in virtually any publication dedicated to the problems of modern society and its political development. However, it should be noted that there is very little research on this topic, which indicates, first and foremost, the lack of analytics affecting this particular area of concern. Accordingly, its lack affects the effectiveness of political decisions. This means that there is an objective socio-political order for research on political risks: the creation of methods for their selection and evaluation, as well as the development of methods for its accounting and reduction in the organization of political activity.

This area was most developed in the USA. It is there, since the late 1950 s, that various concepts and theories have been intensively developed to underpin political risk issues. This is, first of all, the theory of modernization, the ideas of popular capitalism, the welfare state, neoliberalism, the theory of globalization, etc.

\footnotetext{
${ }^{2}$ Найт Ф. Понятие риска и неопределенности. THESIS. 1994. № 5. С. 22.
} 
Also, the impetus for the development of this direction in political science was the emergence of a systematic approach, cybernetics, mathematics, etc. Their widespread use as a methodological basis for sociopolitical sciences in the $1950 \mathrm{~s}$ and $1960 \mathrm{~s}$ led to an interdisciplinary synthesis. The result is a rapid development of new theories and applied political studies, one of which in the US is the concept of political risk.

The development of US political risk research has undergone several stages, each reflecting the specifics of the internal and external political situation and, to some extent, the achievement of applied management and political science. There are several stages in the development of this theory: the «phenomenon of growth» (1950-60), «flourishing» (1970s - early 1980s), «difficult» (1980s).

At the turn of the 1950s and 1960s, the classic concept of political risk was born. It has traditionally been associated with the events in Cuba in 1959, when, after Fidel Castro came to power, the ownership of foreign companies was nationalized. Then, in the 1960s, a number of fundamental works emerged, focusing on the issues of political risk assessment and management. At the same time, political risk means, first and foremost, the damage suffered by a corporation as a result of adverse political events: nationalization, confiscation, political and natural unrest. The purpose of those years' research was to provide guidance on protecting the interests of American TNCs and their financial resources. Most of these papers address the political risk analysis of corporations at the international level. Therefore, at this stage, numerous theories of transnational corporations, organization theory, practical experience of companies regarding their interaction with the external environment, as well as the theory of international business have played a significant role in political risk research.

At the same time, the need for political risk analysis was exacerbated by the fact that in the conditions of the struggle of two ideologized systems: the capitalist and the socialist, a political factor was of great importance. Understanding this situation - one of the reasons for the organization, special departments of political risk analysis as an independent structural unit in Western TNCs since the late 60's - early 70's of the 20th century. The expansion of their activities in «third world» countries encountered various trends that had an adverse effect on business: nationalization of property, expropriation, coups, civil and partisan wars, other forms of political instability. The practical needs of business and government circles in the West in managing capital, in the face of political instability and developing theoretical risk studies have led to the development of an entire 
market infrastructure of services to serve the needs of business in risk management.

During the 70-80s of the 20th century, the focus of research attention was broadened in applied political risk analysis. This phase is linked to the 1979 Islamic Revolution in Iran, which forced Western political and academic circles to reconsider conceptual and applied approaches to securing Western representation in the Third World. During this period, which lasted until the mid-1980s, interest in the issue of political risks peaked, but eventually faded away.

The third stage comes in the so-called «difficult»1980s. At this time, the search for reasons for the failure of the application of the concept of political risk in the analysis of the development of different political and economic systems, and attempts to rethink these concepts. Analysts and politicians are convinced that military-political methods, including diversionary measures against the leadership of various states, traditionally used by the US government to protect the economic interests of their corporations, do not always produce the expected results and should be used as a secondary factor in achieving political goals.

In other words, it has become necessary to develop effective tools to anticipate negative events in the political sphere and evaluate their consequences. This has led to the creation of a worldwide network of specialized centers, both commercial and non-commercial, for the analysis and forecasting of political risk. In Western countries, there are more than 500 such organizations, the vast majority of which are in the United States. These organizations study various aspects of political risk and make proposals for political risk management.

\section{Problems of political risk at the level of applied political science}

The problems of political risk that are required in assessing its level of consideration of the complex diversity of different political and social factors relate to applied political science. However, political risk management at the present-day level requires an appropriate scientific base, the development of which plays a fundamental role in basic research in the field of political science, in particular, works that develop contemporary ideas about political and social processes and their patterns. This is a study of applied political science, which studies the issues of stabilizing the internal political situation and must take into account the laws that are important in assessing political risk.

In foreign practice, issues of applied political science are quite often addressed in the literature devoted to strategic planning and management. 
Important provisions on the nature of political risk are contained in works on applied political science by authors such as D. Abell, V. Asher and V. Overholg, I. Ansoff, G. Steiner and many others. Among the Soviet authors who considered political risk, one might call A.P. Algin, who believes that exploring the place and role of risk in the restructuring process is one of the aspects of meeting the requirements of increasing the attention of the social sciences to practice, their addressing the real goals and needs that are relevant in life. Publications in this field have also started to appear in our country, some of which are listed in the sources used.

Classical science defines risk as an objective, manageable, weighted phenomenon. Because of this, the risks are the dangers of technology and natural disasters. C.Star and his followers (R.R. Appuluri, R. Beit, M. Waterstone, W. Werner, M. Douglas, J. Edems, W. Covello, L. Cool, M.J. Cooper, L. Lave, V. Leiss, V. Lawrence, A. Moissy, P. Ricci, J.V. Rodricks, V. Rove, W. Hauptmannns, J. Hendmer, P. Stern, H. Feinberg, K. Chosiolko, M. .Subik et al.) raised the problem of the mismatch of risk perception by scientific, industrial and governmental structures on the one hand, and the public on the other. In their view, the only problem here is people's response to risk, which is generally not rational. The main discussions within this paradigm are around the concept of «pleasant» («acceptable») risk.

Socially oriented scholars (R. Grove-White, S. Jasanoff, M. Douglas, J. Edems, R. Catherine, D. Mayo, R. Hollander, D. Nelkin, M.T. Thompson, S. Rainer, K. Hood) seek to demystify technical risk analysis, enhance the role of social protection and enhance the value of political culture.

Psychology considers risk as a subjective phenomenon that implies choice in alternative situations (B. Bremer, A. Vyks, K. Hood, D. Jones, H. Joe, N. Kogan, M. Volesh, S. Krimsky, X. Margolis, R. Trimpop, F. Jatz). Separate risk areas in psychology are the theory of prospect («prospectus») of A. Tversky and D. Kaneman, who refer to the prospectus as «bet» as a «game» with possible results, and psychometric theory of decision-making by P. Slovik and Y. Kozeletsky, according to by which people tend to behave rationally. Here, risk is seen as an element of the decision-making and implementation process that is usually associated with measuring the likelihood of an error or the success of a given choice in a multi-alternative situation. The risk of making individual decisions is motivated, appropriate. The risk of group decisions is more objective, but destructive processes in group dynamics often reduce the level of group interaction, which increases the possibility of unreasonable risk. Such a 
feature is accepted to be explained by the phenomenon of group thinking, which I. Janis drew attention to.

In jurisprudence, risk is seen as an event that creates disorder, harms, and allows one to identify who is the victim and who is the offender (F. Ewald, K. Coleman, J. Simon).

Economic theory explores risk in the context of decision making. The problem of business riskiness was raised by the classics of modern economic theory such as A. Smith, D. Ricardo, M. Weber, J. Schumpeter, J.M. Keynes, J. Galbright, K. Arrow, F. Knight, etc. In modern western economic science, two theories of risk have been formulated: classical (risk as the probability of damages and loss from the chosen decision and strategy of activity (J. Mill, I. Senor)) and neoclassical (risk is the probability of deviation from the set goals (A. Marshall, A. Pigu, J. Keynes, K. Arrow, F. Knight).

In considering the place of political risk problems in the system of scientific knowledge, the socio-philosophical analysis of this concept deserves special attention. This is important to provide the necessary depth of understanding of the content of the political risk concept and to develop modern perceptions of it as a particular scientific category. For example, in the works of A.P. Algin the idea is presented that this concept reflects the common features inherent in the categories of human cognition of the environment. Therefore, when considering the concepts of risk and, accordingly, political risk from a methodological point of view, it is advisable to analyze the nature and internal contradictions of the properties of these concepts related to the characteristics of activities, including political. This approach to the concept of risk opens new opportunities for theoretical research, allows to introduce into the field of philosophical knowledge those aspects and nuances of social reality, human activity, which are difficult to detect, but which create the preconditions for deepening the content of already known categories. From this perspective, we can analyze the relationship of this concept with different philosophical categories. It is noteworthy, for example, the relationship of the concept of political risk to such categories as necessity, chance, uncertainty, objectivity and subjectivity.

It should be noted that in modern Ukrainian science, the problems of risk, riskology are most developed in the economic aspect, namely in the areas of consideration of investment risks, mechanisms of risk management, entrepreneurial risks, economic activity, etc. A lot of thorough research is devoted to this layer. These are the works of such scientists as M. Damaskin, 

A. Gryschenko,
M. Stepur,
O. Taran,
L. Bondarenko,
O. Kolot,
N. Skopenko, V. Kryvoshein.

As V. Gorbatenko correctly determines, «the main areas of political riskology, which is gradually becoming the domain of applied political science, are: analysis and assessment of non-commercial risks for international business; decision making in conditions of socio-political uncertainty; venture (risky) political technology. Research on political risks is needed first and foremost by the decision-making bodies in the country or region, as well as by banks, firms, organizations planning to invest their capital in certain countries or regions. $\rangle^{3}$.

Another aspect I would like to highlight is the presence of an appropriate level of uncertainty, which is one of the important features and a risk environment. However, such uncertainty must be objectively existing, that is, due to the unpredictability of the actions of socio-political actors, the spontaneity of phenomena that occur in nature and society, the limited resources in decision-making and implementation, as well as the lack of knowledge of the surrounding reality. Uncertainty acts as a reflection on multivariate, ambiguous social and applied processes. It is organically inherent in the whole process of social development, because any stage of it always contains the possibility of change, including qualitative ones, caused by internal and external factors, which are not taken into account due to limited knowledge or subjective mistakes of persons, decision makers. This means the objective impossibility of accurately predicting socio-political events.

Sources of uncertainty in society are diverse. Common reasons that contribute to the creation of uncertainty and subsequently risk situations are usually indicative of limited resources (material, financial and other) in making and implementing decisions, incompleteness or distortion of available information, inability to unambiguously disclose the content of phenomena or processes. Uncertainty is generated by the existence of many differences in socio-political attitudes, ideals, assessments, stereotypes of behavior and values of people in relation to various social relations, as well as under the influence of the results of scientific and technological progress on the socio-economic, political and spiritual conditions of social development. That is, uncertainty is associated with the ability to capture the occurrence of a variety of situations and consequences in a subject's activity.

There are two main types of risk that need to be considered in order to understand what is happening in the world today. The first kind can be

${ }^{3}$ Горбатенко В. П. Політичні ризики: від теорії до практики. Суспільно-політичні процеси. 2016. Вип. 2. С. 55-69. URL: http://nbuv.gov.ua/UJRN/pubpolpr_2016_2_4. 
conditionally called external risk. External risk is a risk that is beyond ourselves: it is related to unchanging traditions or laws of nature. Another variation is the risk associated with our knowledge of the outside world. The category of man-made risk includes situations that humankind has virtually never encountered before in history, for example, most of the environmental risks associated with global warming. Increasing globalization has a direct impact on them.

From a realistic approach, risk means a state of danger, a threat that causes people's desire to protect themselves from possible losses. Risk, in this case, is considered in scientific, technical and economic terms used in economics, statistics, ecology, insurance, epidemiology and emergency management. The starting point of risk here is the concept of danger (harm), as well as statements about the possibility of predicting their occurrence and measuring the consequences. Risk is interpreted as an objective and recognizable fact - a potential danger or already caused harm that can be measured regardless of social perception and cultural environment. At the same time, supporters of this approach recognize that the risk can be misjudged in the framework of one or another way of social interpretation.

In the narrower aspect, risk is understood as activity in the transition from a state of uncertainty to a state of certainty (or vice versa), when a reasonable opportunity to choose when assessing the probability of achieving the expected result, failure and deviation from the goal, taking into account the existing essential norms. It should be emphasized here that risks are constructed through the active perception and selection of people in a process determined by social goals and norms of social activity. On this basis, another scientific area of risk research emerges, focusing on philosophical, social, political and cultural aspects.

We can distinguish the following areas of risk analysis: the cultural and symbolic direction (M. Douglas), the concept of «risk society» (W. Beck and E. Giddens) and the concept of «calculative rationality». Interesting models of sociological studies of risk are also proposed by I. Devyatko and $\mathrm{K}$. Gavrylov. In each of these approaches, there is a moderate and radical line of understanding of risk. Proponents of the moderate concept believe that risk is an objective and subjective reflection of the existing danger. Proponents of radical theory claim that there is no risk as such. One can only talk about the subjective perception of risk, which is due to economic, spiritual, political and social factors and conditions that are specific to a particular social or political situation.

It should be noted that the scientific literature ambiguously interprets the ratio of objective and subjective causes of risk. The objective moment of risk 
is the various conditions, factors, states of collective and individual development, culture, traditions, etc. that exist outside the consciousness of the actor. Risk is objective because it is a form of qualitative and quantitative expression of existing uncertainty. Risk is an attribute characteristic of an activity, because the activity as such is almost always accompanied by uncertainty and the likelihood of finals. On the other hand, risk is the attitude and means of action of the subject, which are based on inherent inherent in him, subjective needs, interests and motives of activity. The subjective nature of the risk is based on the premise that the subject of the action makes the decision to choose a particular alternative of behavior in uncertainty.

Each of these approaches has strong arguments for recognizing both the subjective and objective nature of the risk. Therefore, the subjectiveobjective concept of risk has become most widespread. Its main argument is the recognition that the outside world knows no risk, because it knows neither discernment, nor expectation, nor assessment, nor probability. Thus, risk is the dialectical unity of objective and subjective. Risk researchers note that the subjective-objective nature of risk is also traced in the etymology of the word «risk», which can be interpreted as «maneuvering between rocks», where the former is subjective and the latter is objective.

The presence or absence of analogues of solutions to solve existing risk situations gives reason to speak of ordinary and extraordinary risks. If in the pre-industrial society there were traditional risks, then in the industrial age there are preconditions for technological risks. The latter arise as a result of collective decisions or as a result of the accumulation of a large number of actions by individual social actors. The peculiarity of new risks is that they cannot be the object of direct observation, given their complex nature. As a result, these risks are usually undetermined and their effects are unpredictable.

In the mid-1980's, Perro introduced into circulation the sociology of the notion of «normal accidents», which he understood «inevitable (structurally) failure of technology in complex technological systems - nuclear power plants, petrochemical enterprises, air traffic control systems. As system failures occur due to the complex interaction of technical components, therefore, no fault should be found among the service personnel». According to Perro's words, «the effort to find specific entities responsible for such accidents is driven primarily by the focus on economic growth and the political interests of the economic elite, which underlies the risk assessment 
process itself» ${ }^{4}$. This opinion seems to be quite controversial, which can be agreed upon in the case of technical and technological problems of these systems, which arise in the course of their operation, but are not caused by erroneous technological or design decisions. In other cases, it is wrong to speak of the entire removal of human responsibility for the occurrence of technological disasters, a convincing proof of which is the Chernobyl disaster in 1986.

The risk comes when the number of potential negative consequences can exceed the number of potential positive consequences. In this case, it is a risk as an event (fact), whereas it is necessary to analyze first of all the social and political conditions in which the occurrence of the risk is most favorable and, accordingly, to focus the efforts of the researchers on its prevention or minimization. The focus is on analyzing three types of systems that produce risks in today's society: natural, technological and social.

Although it is not possible to establish a commonly accepted subject definition of the concept of «risk», most scholars note the following essential signs of risk.

- The risk comes from the fundamental uncertainty of reality. Lack of information, the spontaneity of many phenomena that occur in people's lives, limited resources in decision-making and implementation, and the presence of antagonistic tendencies in socio-political development create elements of uncertainty and chaos, creating conditions for risk. The uncertainty category is the basis of an information approach to understanding the nature of risk.

- The probabilistic nature of the occurrence of both adverse and favorable effects of risk. This means that the risk cannot be limited only by the probable loss or damage. Risk carries with it not only the negative but also the positive possibilities, which are taken into account and used as an important point in the decision-making process regarding certain risks. These two aspects of risk - its negative and positive sides - have emerged already in modern times. Probability, in this case, is defined as the objective possibility of an event occurrence.

- Relation of achievement of the set goals and results. Human activity is influenced by factors whose essence and power cannot always be objective and measured in absolute terms. The constant change in the priorities of one interest in relation to others creates situations where the achievement of any results previously considered relevant and productive and in certain

\footnotetext{
${ }^{4}$ Perro J. Crisis hits European car makers. Radio Nederland Wereldomroep. Brussels. October 30, 2008. URL: http://static.rnw.nl/migratie/www.radionethernands.nl/ currrentaffairs/region/Europe/081030-++europe-car-crisis-me-redirected.
} 
circumstances may be reversed among the participants in the political process. Lack of confidence in the subject can lead to arbitrariness and mistakes in assessing the nature of personal and group interests and in conflict situations.

- Orientation to the future. Risk is expressed in reality, which includes elements of goal setting, forecasting and planning of expected states, processes and phenomena. That is, risk appears as a reaction to the situation. As a result, the future risk component makes it a critical setting in the decision-making process and a central category in describing the future. Risk should be seen as a specific form of socio-political communication aimed at assessing the unknown future in the present.

- Controversy. Risk contributes to the implementation of initiatives, innovative ideas, social experiments. This gives you a chance to overcome the inertia, stereotypes and limitations that hinder innovation. On the other hand, it can lead to voluntarism, underestimation of the essential aspects of life, to certain political, socio-economic, legal and moral conflicts. Especially if the decision is made without adequate patterns of development of the situation of preparatory measures.

- Alternative. Risk involves choosing from two or more options. In the absence of a choice, the risk as such is impossible. In this case, the situation can be characterized by a state of «certainty». But, it should be emphasized that refusal to choose is also an option, an alternative. Depending on the specific content of the choice situation, the alternative has varying degrees of complexity and is structured by different means. To do this, we use the classification of problematic situations that require the choice of an alternative. There are three types of tasks: well-structured, poorly structured, and unstructured. Each type of task is answered by a specific set of methods and techniques for analyzing, evaluating and formulating recommendations.

- Evolutionary. Both external and internal risks are able to evolve. Among the risks are the natural selection and the many mechanisms of transformation, conditioned by the nature of the objects in which they must be. Impact on risk involves the answer of reducing its level, but it cannot be completely eliminated because the initial risk will be changed and can be transformed into a number of other risks.

Thus, risk is a concept that has a certain scientific status. As a result of multidimensionality and universality, risk is the object of many interdisciplinary studies, and the term itself is a general scientific concept. Transformation of an abstract concept into concrete terms based on subjective preferences and the transition from conceptual comprehension to operational disclosure of a problem is the main task of any science. 
The concept of risk is linked, according to Giddens, with an active analysis of the danger in terms of future consequences and is therefore widely used only in the future-oriented society for which the future is an area to be conquered or colonized. In this respect, the concept of risk begins to compete with the once basic categories of social development. The future is increasingly being described in terms of risk, not progress 5 .

Theoretical and conceptual approaches to risk determination have been developed in the broadest context of the most extreme states of society and reflect the economic, cultural, political, socio-environmental, legal aspects of risk. This demonstrates the interest in the study of the ricogeneous components of phenomena, both from the representatives of technical knowledge and, to a great extent, by thinkers of the social sciences. The dynamics of the growth of risk concepts reflects the change in the substantive content of risk in the process of development and complexity of structures of modern societies.

At a practical level, we are talking about risk management. The subject of research in risk management is the phenomenon of risk in its various applied levels and is considered, in most cases, in the instrumental aspect. The focus is on analyzing and finding effective means of communication, decision-making and management in situations of risk in certain areas of human life: political risks, business risks, military security risks, psychological and communication aspects of risk, risk management in emergencies legal and enforcement risks, managerial risks.

Another point to be made is the socio-perceptual concept of risk, which defines the parameters of risk perception as a possibility of predicting the risks associated with a subjective decision. In the framework of this concept an attempt is made to study in depth the risk as a factor that shapes the behavioral space of the individual. The risk perception process is characterized as a dynamic process because it is not a constant process and may change over time; so, it is an interactive phenomenon, because individual risk perception is indirect risk perception by the local community. It should be noted that the impact of social institutions on minimizing the impact of risks changes their social interpretation.

$\mathrm{N}$. Luman proposed a scheme to distinguish between risk and danger. Risk is understood here as «an objective and cognitive fact that can change regardless of social or political processes and cultural environment. In today's society there is no risk-free behavior. If for the «risk-reliability dichotomy» means that there is no absolute reliability (i.e. safety), whereas for the «risk-hazard» dichotomy, this means that risk cannot be avoided by

${ }^{5}$ Гидденс Э. Судьба, риск и безопасность. THESIS. 1994. № 5. С. 120. 
making any decision. The better people get to know what they didn't know before, the deeper their awareness of risk becomes. The more rational and detailed the risk measurement becomes, the more aspects of it become known to people» ${ }^{6}$.

Based on J. Ritzer's McDonaldization of Society theory, one can identify the following characteristics of social risk in modern society: «risk becomes compact, which means that risk can be concentrated in compact objects; social risk production is simplified; social risks are «scienced» (from English «science») by their internal structure» ${ }^{7}$.

Proponents of the cultural and symbolic concept try to prove that risk is a socio-cultural fact that differs from natural cataclysm and arises in the case of risk of harm to the subject or object of risk realization or insufficient protection against the danger. Risk-anxiety and risk-tolerance are cultural orientations that influence the level of risk-taking in society.

Cultural and symbolic concepts are represented in three directions: the first is related to the specificity of the culture, which poses a particular level of risk; the second - with historical dynamics as a specific source of new risks; the third - with the development of cultural risk management technologies.

The founder of the theory of «calculative rationality» M. Foucault and his followers focus on explaining how different risk concepts generate specific behaviors that can be used to motivate individuals to participate freely in self-organizing processes in risky situations ${ }^{8}$.

Some researchers, including O. Renn, P.K. Stern, H.V. Feinberg, E. Peters, et al., have proposed a synthetic approach to risk research, pointing to a combination of risk structures and changes in the hierarchy of social values affected by risk. This approach is linked to the concept of risk, which underlies the pursuit of risk or the benefit of it as a life strategy. An attempt to combine the cultural-symbolic approach, the problems of the «risk society» and M. Foucault's arguments in order to give a synthesized understanding of risk as a social phenomenon is to create a socio-cultural theory of risk (works by D. Lapton, P. Kaplan, E. Scott). This area provides

\footnotetext{
${ }^{6}$ Луман Н. Понятие риска. THESIS. 1994. № 5. С. 137.

${ }^{7}$ Ритцер Д. Макдональдизация общества. Москва: Праксис, 2011. С. 56.

${ }^{8}$ Фуко М. Безопасность, территория, население. Лекция 25 января 1978 года. Цикл лекций, прочитанных в Колледж де Франс в 1977-1978 годах. Гуманитарные технологии: Аналитический портал. URL: https://gtmarket.ru/library/articles/6693/6696.
} 
an «important perspective description and examples to study, but limited in theory or discussion» ${ }^{9}$.

\section{CONCLUSIONS}

The gradual awareness of the global community of the fundamental risktaking of any social production stimulates the process of creating technical and social systems that minimize man-made risks. Three fundamentally different but interconnected types of social technologies have been created to combat the risks of the modernization era. Firstly, technology to minimize the production of risk, including closed-loop production. Secondly, the technology of protection against the introduction of industrial safety rules to international collective security systems. The result is an appropriate legislative framework at the international level and active institutions that support certain norms of political risk.

Thus, in risk theory, there are many definitions from different perspectives, as well as its classifications, that illustrate this complex concept. If you try to summarize these definitions, you can combine them into the following two. Risk is defined as a predictable event that could cause damage or harm to someone, that is, have negative consequences. Risk is a specific category that characterizes the deviation of the actual result from what is expected, i.e. there can be both negative and positive consequences from an event or process. The level of risk is almost always proportional to the expected costs caused by the risk event and the likelihood of its occurrence.

Risk theory has reached a new level of cognition when scientists begin to distinguish between theoretical and effective risk, which are related to the concept of eventual risk, which arises when modeling risky situations taking into account the peculiarities of risk perception by the subject. In the case of social risk, the purpose function is to solve social problems and the political aspects are taken into account in the risk factors. For political risk, on the contrary, the purpose function is related to political problems, and indicators of social and economic processes are taken into account when it comes to risk factors.

Assessing the degree of elaboration of the problem of political risk in modern science and the relevance of the study of this phenomenon in modern political processes, we can determine that this problem is stated and studied, above all, in philosophical and socio-economic aspects. The

\footnotetext{
${ }^{9}$ Кривошеїн В. Культурологічна теорія ризику в структурі політичної ризикології. Науковий вісник Ужгородського університету. Сер. Політологія, соиіологія, філософія. 2009. № 12. C. 28-33.
} 
political aspect of the study of this topic is only in its infancy. Theoretical underdevelopment of the problem complicates the management of real political risks, optimization, rationalization of practical management activities in political activity.

\section{SUMMARY}

A study of risk and political risk in the context of adaptation to the conditions of the globalized world, taking into account democratic tendencies, has been made. It is determined that the relevance of the study of risks in politics and political risks is connected with the need to analyze, predict and model the development of political processes in order to preserve statehood and realize their own interests in the framework of democracy. It is justified that the risk theory today has reached a new level of cognition, when scientists began to distinguish between theoretical and effective risk, which are connected with each other by the concept of eventual risk, which arises when modeling risky situations taking into account peculiarities of risk perception by the subject. It is determined that for political risk, the purpose function is related to political problems, and indicators of social and economic processes are taken into account when it comes to risk factors.

\section{REFERENCES}

1. Perro J. Crisis hits European car makers. Radio Nederland Wereldomroep. Brussels. October 30, 2008. URL: http://static.rnw.nl/ migratie/www.radionethernands.nl/currrentaffairs/region/Europe/081030++europe-car-crisis-me-redirected.

2. Гидденс Э. Судьба, риск и безопасность. THESIS. 1994. № 5. C. $116-134$.

3. Горбатенко В. П. Політичні ризики: від теорії до практики. Суспільно-політичні процеси. 2016. Вип. 2. С. 55-69. URL: http://nbuv.gov.ua/UJRN/pubpolpr_2016_2_4.

4. Кривошеїн В. Культурологічна теорія ризику в структурі політичної ризикології. Науковий вісник Ужгородського університету. Сер. Політологія, соціологія, філософія. 2009. № 12. С. 28-33.

5. Левченко М. О. Політичний ризик як один із факторів впливу зовнішньоекономічної діяльності машинобудівного підприємства. Економічний вісник Донбасу. 2011. № 2(24). С. 53-57. URL: http://www.evd-journal.org/download/2011/2011-2/Ek_visnyk_2_2011-5357.pdf.

6. Луман Н. Понятие риска. THESIS. 1994. № 5. С. 135-160. 
7. Найт Ф. Понятие риска и неопределенности. THESIS. 1994. № 5. C. 20-24.

8. Ритцер Д. Макдональдизация общества. Москва: Праксис, 2011. $592 \mathrm{c}$.

9. Фуко М. Безопасность, территория, население. Лекция 25 января 1978 года. Цикл лекций, прочитанных в Колледж де Франс в 19771978 годах. Гуманитарные технологии: Аналитический портал. URL: https://gtmarket.ru/library/articles/6693/6696.

\section{Information about the author:} Pekhnyk A. V.,

$\mathrm{PhD}$ in Political Sciences, Associate Professor, Associate Professor at the Department of Political Theories of the National University «Odessa Law Academy» 2, Academichna str., Odesa, 65009, Ukriane 